\title{
INFORMATION SYSTEM FOR SCIENTIFIC STUDY \\ OF THE MICROMETEOROLOGY OF KARST CAVES - CASE OF POSTOJNSKA JAMA CAVE, SLOVENIA
}

\section{INFORMACIJSKI SISTEM ZA ZNANSTVENE RAZISKAVE MIKROKLIME V KRAŠKIH JAMAH: PRIMER POSTOJNSKE JAME, SLOVENIJA}

\author{
Primož MLAKAR ${ }^{1^{*}}$, Boštjan GRAŠIČ $\check{1}^{1}$, Marija Zlata BOŽNAR ${ }^{1}$, \\ Darko POPOVIĆ ${ }^{1} \&$ Franci GABROVŠEK ${ }^{2}$
}

\begin{abstract}
UDC 681.518.3:551.584.6(497.4Postojna Primož Mlakar, Boštjan Grašič, Marija Zlata Božnar, Darko Popović \& Franci Gabrovšek: Information system for scientific study of the micrometeorology of karst caves - Case of Postojnska jama cave, Slovenija

The paper presents the construction and operation of a cave information system on the example of the Postojnska jama cave. It thoroughly describes the construction of the basic modules of the cave information system, such as an automatic cave measuring station with sensors for measuring air temperature, air flow and $\mathrm{CO}_{2}$ concentration, and a central unit for collecting, saving, processing and displaying data. The system provides quality automatic measurements for the scientific study of the micrometeorology of karst caves. Its construction is based on good practices stemming from many years of experience in taking measurements in the external atmosphere and in karst caves. The paper is rich and comprehensive guideline for automatic cave measuring system construction for scientific and tourist management purposes.

Key words: automatic measuring system, quality measurements implementation and assurance, karst caves, microclimate, guideline.
\end{abstract}

\begin{abstract}
Izvleček
UDK 681.518.3:551.584.6(497.4Postojna Primož Mlakar, Boštjan Grašič, Marija Zlata Božnar, Darko Popović \& Franci Gabrovšek: Informacijski sistem za znanstvene raziskave mikroklime v kraških jamah: Primer Postojnske jame, Slovenija

$\mathrm{V}$ članku na primeru Postojnske jame predstavimo izdelavo in delovanje jamskega informacijskega sistema. Podrobno opišemo izdelavo osnovnih gradnikov sistema. Mednje spadajo jamska merilna postaja s senzorji za merjenje temperature, vetra in koncentracije $\mathrm{CO}_{2}$ ter centralna enota za zbiranje, procesiranje in prikaz podatkov. Sistem zagotavlja kakovostne avtomatske meritve za znanstvene raziskave jamske mikroklime. Zgradba sistema temelji na dolgoletnih izkušnjah iz okoljskih meritev v jamskem in zunanjem okolju. Članek je tudi priročnik za izgradnjo avtomatskih merilnih sistemov za raziskovalne namene in za podporo pri upravljanju turističnih jam.

Ključne besede: avtomatski merilni system, kakovost meritev, izvedba in zagotavljanje, kraške jame, mikroklima, priročnik.
\end{abstract}

\footnotetext{
${ }^{1}$ MEIS storitve za okolje d.o.o. Mali Vrh pri Šmarju 78, Šmarje-Sap, Slovenia, e-mails: primoz.mlakar@meis.si, bostjan.grasic@meis.si,marija.zlata.boznar@meis.si,darko.popovic@meis.si

${ }^{2}$ Karst Research Institute ZRC SAZU, Titov trg 2, Postojna, Slovenia, e mail: gabrovsek@zrc-sazu.si
} 


\section{INTRODUCTION}

The scientific study of the micrometeorology of karst caves requires quality automatic measurements of various physical quantities at measurement sites in different locations for which we presume will give us an adequate description of the main events within the cave. The World Meteorological Organization has provided detailed recommendations (World Meteorological Organization 2008) for the quality monitoring of physical quantities in the external atmosphere, whereas no similar recommendations have yet been provided for the monitoring of micrometeorology in karst caves.

Quality data are those data which meet the predefined requirements, such as accuracy or uncertainty, resolution, representativeness, timeliness and other requirements, which depend on the intended use. Quality measurements can be ensured by using appropriate sensors, converters, appropriate computer-aided processing, and a suitable automatic data quality control system. Even though none of the measured data are ideal - they have a greater or smaller measurement uncertainty they can be used for a specific purpose if their quality is known (World Meteorological Organization 2008).

In addition to these issues it is also important how to build an automated measuring network. Automated environmental networks for atmospheric and air pollution measurements are discussed in several papers (Lesjak et al. 1989, 1999a,b; Mlakar \& Božnar 1995; Mlakar et al. 1999, 2006, 2014; Božnar 2004; Mlakar et al. 2019). All authors describe details of software and hardware solutions implemented in automated measuring networks in Slovenia, which has a dense network of automated stations. We have transferred rich experiences from measurements in the free atmosphere to design and implementation of automated cave measuring networks (Grašič et al. 2017a, b).

Similar approaches were described also by other authors. Marikovičová et al. (2015) describe in details their information system for monitoring cave microclimatic and environmental conditions for scientific research, where the challenge of relative humidity measurement is outlined. In the paper by Cigna (2002) modern trend in cave monitoring is presented using two cases of cave information systems used in Kartchner Caverns, Arizona, USA and Cango Cave in Africa. Zelinka (2002) presents the activities of the Cave Protection Department of the Slovak Caves Administration in speleoclimatic monitoring in the Slovakian show caves since 1996. Novas et al. (2017) present a real-time cave monitoring system in"El Soplao" Cave in the North of Spain to preserve and achieve sustainable tourism.

We present the experiences and findings gained from designing and providing quality automatic measurements for the scientific study of the micrometeorology of karst caves. The work is based on good practices and an appropriate supplementation and adaptation of the recommendations of the World Meteorological Organization for measurements in the external atmosphere (World Meteorological Organization 2008).

\section{MODULES OF THE CAVE INFORMATION SYSTEM}

The cave information system is made up of several automatic cave measuring stations, data transfer nodes and a central cave unit. In representative locations, the cave measuring stations continuously take measurements of various environmental parameters (e.g., air temperature, $\mathrm{CO}_{2}$ concentration, etc.) in predefined time intervals for sampling and statistical processing, and transmit them to the central unit in digital form.

The central unit can obtain data directly from the cave measuring station or via additional data transfer nodes.

\section{SENSORS}

The cave microclimate is described by measuring the condition of air masses. The main measurements are the measurements of air temperature, relative air humidity and air movement. The $\mathrm{CO}_{2}$ in caves is generally higher than outside and plays important role in karst processes (Prelovšek et al. 2018). Many different sensors for taking these basic measurements can be found on the market. The cave air may also contain other pollutants: natural (radon, biomass decay products) or anthropogenic. Special and expensive measuring instruments are required for measurements of these constituents.

Sensors for air temperature, relative air humidity and air movement are usually adapted for measurements of the external air and not for the special properties of caves. It is therefore very important that appropriate sensors are chosen. The construction of an information system begins with selecting the sensors.

We distinguish active and passive sensors. An example of passive sensor is a platinum resistance temperature 
detector. An active sensor is a capacitive sensor for relative air humidity, which contains a special electrode that produces a voltage output depending on the humidity. Both sensors are analogue. The device to which we connect analogue sensors must have an analogue-digital converter, which converts signals (voltage or resistance) into numbers. Digital sensors already contain such electronic circuits. These circuits digitise analogue signals and enable data transfer usually via serial communication or other.

The selection of sensors also depends on the options of connecting the sensors to the system. If sensors are distributed in a relatively small area, they can be connected to automatic measuring station with inputs for standard analogue sensors, which are cheaper without loss of quality. However, if we are planning a measuring system with individual sensors distributed on larger distances, it is better to choose more expensive sensors, that enable a digital serial transfer across greater distances and a local storage of measurements.

The measurement of relative humidity poses a special problem (Marikovičová et al. 2015). In caves, the relative air humidity is usually close to $100 \%$. It might be lower only near the entrance, where the cave air exchanges more with the external one. In our experience, the affordable and most commonly used capacitive sensors are not applicable for constant measurements of a relative air humidity around $100 \%$, despite the fact that the manufacturers specify a measurement range of up to $100 \%$. That is why we do not recommend constant measurements of relative air humidity in caves.

Besides the high relative air humidity, caves are also characterised by much smaller temperature fluctuations and air movement in comparison with the external air. If we are anticipating smaller changes, then we should use more accurate and stable sensors to capture the weak dynamics of the cave climate.

The choice of sensor is also influenced by its time constant, which should be appropriately small with regard to the method of measuring physical quantities in the cave. For a scientific study in a cave, the sampling frequency must be high enough to meet the Nyquist-Shannon sampling theorem. The theorem states that sampling frequency should be conducted at least twice the frequency of the observed signal (Shannon 1949). In practice, it should be conducted at least at ten times the signal frequency to obtain quality results. We recommend the following values of sampling intervals:

- For air temperature: 10 seconds;

- For air flow: 1 second;

- For carbon dioxide $\mathrm{CO}_{2}: 10$ seconds (or at least under 20 seconds).

The selected sampling frequency is therefore determined both by observed physical quantity in the cave and sensor's response time. For measuring individual physical quantities in caves, we recommend the following sensors based on their characteristics, quality and our experience:

- For air temperature: a passive PT100 resistance temperature detector;

- For air flow: an ultrasonic sensor;

- For carbon dioxide $\mathrm{CO}_{2}: \mathrm{a} \mathrm{CO}_{2}$ probe based on an NDIR sensor (Nondispersive infrared sensor), which uses an IR light absorption method for measuring gases.

\section{AUTOMATIC CAVE MEASURING STATION}

A cave measuring station is made up of sensors connected to measuring interfaces and devices, and an embedded or personal computer. The embedded computer continuously captures, collects and controls data from the measuring interfaces, and transmits them to one or several central units, either automatically or on demand.

When implementing an automatic cave measuring station, its quality depends on the ultimate purpose of the cave information system. Whereas the less accurate indicator gauges (detectors) are sufficient for tourism purposes, the scientific study of cave microclimate requires the use of higher-quality equipment.

The equipment used for scientific use must be of high quality and adaptable, or must have the option of upgrades and additions. The main characteristics of an automatic cave measuring station are:

- The use of a quality measurement interface (data logger) for connecting at least a few sensors to measure various parameters, which enables low energy consumption; additional data storage to its own permanent memory medium (e.g., a CF card), which is adaptable and resistant to extreme weather within the cave, and can be reprogrammed;

- The use of an advanced uninterruptible power supply, which is based on a microcontroller with exceptionally low energy consumption and ensures: a good condition of the battery; continuous operation despite shorter power outages (at least up to 2 days); signals the operating system in advance that it is about to shut down to protect the data on the permanent memory medium, which is sensitive to sudden power outages; and monitors the condition of the battery at least as closely as the other parameters in the environment or in worst case affect the measurements;

- The energy consumption must be minimal and optimised (the current condition of electronics enables a total consumption under $2 \mathrm{~W}$ ), so it does not emit too much heat to the area around the station, which could enable the growth of various microorganisms in the vicinity;

- When supplying electricity, we have to take into account the local electrical "pollution" of the cave and 
the direct impact on measurements; active sources, such as fuel cells or aggregates are not suitable because they release $\mathrm{CO}_{2}$ and overheat; as of yet, the only option is supplying electricity using long cables (this requires more construction work to ensure an uninterruptible power supply) or batteries (simpler installation, but they have to be charged periodically);

- As much as possible electronic parts of the measuring equipment should be designed to operate with extra low power supply voltages to be safe for humans in usually wet cave environment to carry a low risk of dangerous electrical shock; according to EU's Low Voltage Directive (European Union 2014) define an ELV device or circuit as one in which the electrical potential between conductor or electrical conductor and earth (ground) does not exceed $50 \mathrm{~V}$ AC or $75 \mathrm{~V}$ DC;

- The sensors have to be properly protected against condensation and falling water drops (e.g., a $\mathrm{CO}_{2}$ sensor with its own heating system or a small canopy, etc.), and the connectors too; during installation we must make sure we do not cause water retention or must ensure its drainage;

- The use of a suitably insulated housing, which prevents condensation on the housing through the waste heat from the used electronics; condensation occurs in caves despite the air temperature that is relatively unvarying compared to the external air, because caves usually have $100 \%$ relative humidity; silica gel can help additionally but it is not sufficient by itself for long term operation;

- An IoT (Internet of Things) embedded computer based on a standard embedded operating system (embedded Linux) with a suitable permanent memory medium (a microSD card), the option of an Ethernet and/or WiFi connection, and a connection via RS232/ RS485/RS422 or USB with a measuring interface (data logger) is suitable for local storage and/or communication to central unit when data logger itself cannot fulfil that task.

The software of a quality automatic cave measuring station has the option of smaller enhancements and customizations in the field in the form of setup files, and the upgrade option. It comprises a group of different programs that ensure a continuous and ongoing capture of data from the sensors, and the transmitting of processed data to the central unit:

- A program for the capture, statistical processing and control of signals from the sensors;

- A program for local data storage for a limited period (at least up to 1 month);

- An additional program for the local basic visualisation of data at the measurement site;
- A program for the transfer of data to the central unit;

- And a "watchdog" program for controlling the operation of all other programs (shutdown and restart in the event of a malfunction).

Automatic control of data from the sensors (Mlakar et al. 1990) is essential for a long-term quality operation of the automatic cave measuring station. The basic task of data quality control is the ongoing automatic data verification. If an error is detected in the measurement, such data are labelled invalid, but are nevertheless sent to the central unit, where they automatically warning alarm of the error and are used to analyse the error before sending operators to the field. One example of an automatic control is verifying whether the constant air flow velocity is outside the range, which indicates a sensor malfunction. Another example is checking whether the values are within the prescribed measurement range and whether the standard deviation of the measurement is within the prescribed range (the prescribed ranges are defined for each physical variable separately and may vary in time).

Another important property of an automatic measuring station, which affects the quality of measurement data, is the representativeness of the measurements (World Meteorological Organization 2008). Representativeness is best described by the metadata of the measuring station, which give a detailed description of the type of sensor, its properties, quality, detailed location, calibration date and the sensor's surroundings for each environmental measurement variable. The quality of metadata has improved significantly in cave measuring systems with the evolution of digital cameras, because taking photographs of the automatic measuring station from various angles as changes occur enables us to keep a high-quality database.

\section{CAVE CENTRAL UNIT}

The central cave unit is made up of one or several server computers, which perform many different tasks:

- data collection from automatic measuring stations,

- additional verification and processing of the collected data,

- archiving verified and processed data to a suitably structured historical database,

- ensuring users' access to the database of current and historical data,

- providing access to the display of the last measured values on the public website.

All the measurement data from automatic cave stations are collected, processed further and stored in the central cave unit using various communication channels. The number of central cave units may differ with regard to specific needs.

The quality of the central unit is characterized by the 
tasks it can fulfil; The central cave unit developed by the authors is roughly characterised by the following:

- It is based on a high-performance computer; if need be, individual tasks can be allocated to several interconnected personal computers;

- It must perform all the basic tasks of a central unit, such as collecting data from automatic measuring stations, saving data in their original form (usually in the form of transfer files), archiving data to the database, processing and additional control of data in the database, and providing access to the archived data;

- ACID (Atomicity, Consistency, Isolation, Durability) database:

- the atomicity means that each operation within the database must be fully implemented,

- consistency means that the database must remain uniform and complete after each operation implemented,

- isolation means that the result of a parallel implementation of operations must match the result of a sequential implementation of the same operations

- and durability of data means that after each operation implemented, the database must remain permanently durable.

- Database is also based on:

- an SQL (Structured Query Language) relationship editing database system

- and is compatible with at least the SQL-92 standard (International Organization for Standardization 1992), which is the third major revision of the SQL language for database queries.

- It must have broadband access to the World Wide Web or a local network, which ensures multiple users the option of accessing data simultaneously;

- The time of taking the measurement and the time when the data arrived and was saved to the central unit must be logged in the database for each measurement separately; the difference calculated between the two times determines the data transfer delay and is an important piece of information for system maintenance providers, who can detect problems in the communication channels by analysing these data; it is also important information for the systems in which current data are more important than the delayed ones;

- All of the data saved in their original form, the database, the software and, if need be, the operating system image have to be backed up at regular intervals;

- The long-term quality operation of the central unit is also enabled by an advanced uninterruptible power supply, which ensures continuous operation despite shorter power outages (up to 30 minutes); in the event of a longer power outage, it shuts down the computer equipment in a controlled manner, because most of the permanent memory media (e.g., hard drives, etc.) are sensitive to sudden shutdowns;

- The area in which the computer equipment is located must be properly air-conditioned to ensure its longest possible service life, which is otherwise shortened by exposure to higher temperatures;

- The central unit is equipped with an automatic warning (alarming) system in the event of failed data transfers from the automatic stations and data nodes (communicators), and in the event of a malfunction of other central units and of errors at the stations; this warning system is customizable and enables a daily repetition of warnings. Several types of warnings are possible, based on the roles of the persons being warned (maintenance providers, users), and the warning is carried out via the currently available media (sending short text messages to mobile phones, using email, etc.).

The design and implementation of tourist management environmental systems differs from the ones for scientific research on the level of cave central unit as follows. The main differences lie in the data collection procedures and in the software tools and interfaces for accessing data. In the case of systems for the current control (monitoring) of the environment, it is usually sufficient to have access to current data and a short history in the form of time graphs. Whereas scientific research requires more advance tools for reviewing and analysing long time series data.

\section{CAVE INFORMATION SYSTEM}

Two different approaches (simple tourist management and complex scientific one) that were identified on measuring station level and control unit level are also found on overall information system level. The quality of a cave information system depends on its purpose, since, for example, the construction of a system for just ongoing current control (monitoring) of the cave is less complex and demanding than, for example, the construction of a system for scientific research, which requires a more complex structure and a greater quality of measurements. The processing of measurements also differs. During ongoing control, we are interested only in the latest current/instant or average values. Whereas in a scientific database we want to record the entire dynamics of the observed phenomenon. The least information would be lost by saving all the measurements at a suitable sampling rate. Since we obtain a great deal of data this way, which are usually uncontrollable, we statistically process them for shorter time intervals every $10 \mathrm{~min}$ utes or 30 minutes, and for longer time intervals on a daily, monthly or yearly basis. In these time intervals we record the measurement dynamics with the average value, both extremes, and the standard deviation.

Among other things, the cave information system must also provide user interface with tools for analysis 
and scientific research, such as time graphs, histograms, wind roses, longer time series statistics and sunflower diagrams (Mlakar \& Božnar 1995; Lesjak et al. 2002; Grašič et al. 2003; Božnar 2004; Božnar et al. 2015; Mlakar et al. 2019). Furthermore, such a system must provide and maintain a complete historical database of measurements. The operation of the entire system must be checked and tested by qualified operator periodically on a monthly basis, so we can detect errors, deviations, etc. on time. A highly appropriate method is preparing QA/ QC (Quality Assurance/Quality Control) reports each month, which show and compare all the measurements in time graphs. Another part of the report is the availability, statistics and quality of all the measured variables (parameters), and the visualisation of all the measurements in a suitable way (e.g., wind measurements in the form of wind roses). After reviewing the report, any po- tentially newly discovered invalid data in the database are properly labelled, and a suitable measure for correcting the measurement is prepared, if need be.

A regular, periodical inspection of all the modules of the cave information system (stations, nodes, data mules, computers, etc.) in the field is required at least every three months, regardless of the good results shown in the QA/QC reports. A preventive cleaning of sensors and filters, and a visual inspection of the system's equipment can prevent many unnecessary emergency maintenance works. Sometimes, depending on the modules used, a field inspection is required even more often.

The system will operate better if it contains automation equipment for an ongoing detection of errors in measurements, in data transfers, or in archiving to the central unit. An appropriate warning may trigger a relatively quick implementation of emergency repairs, thus

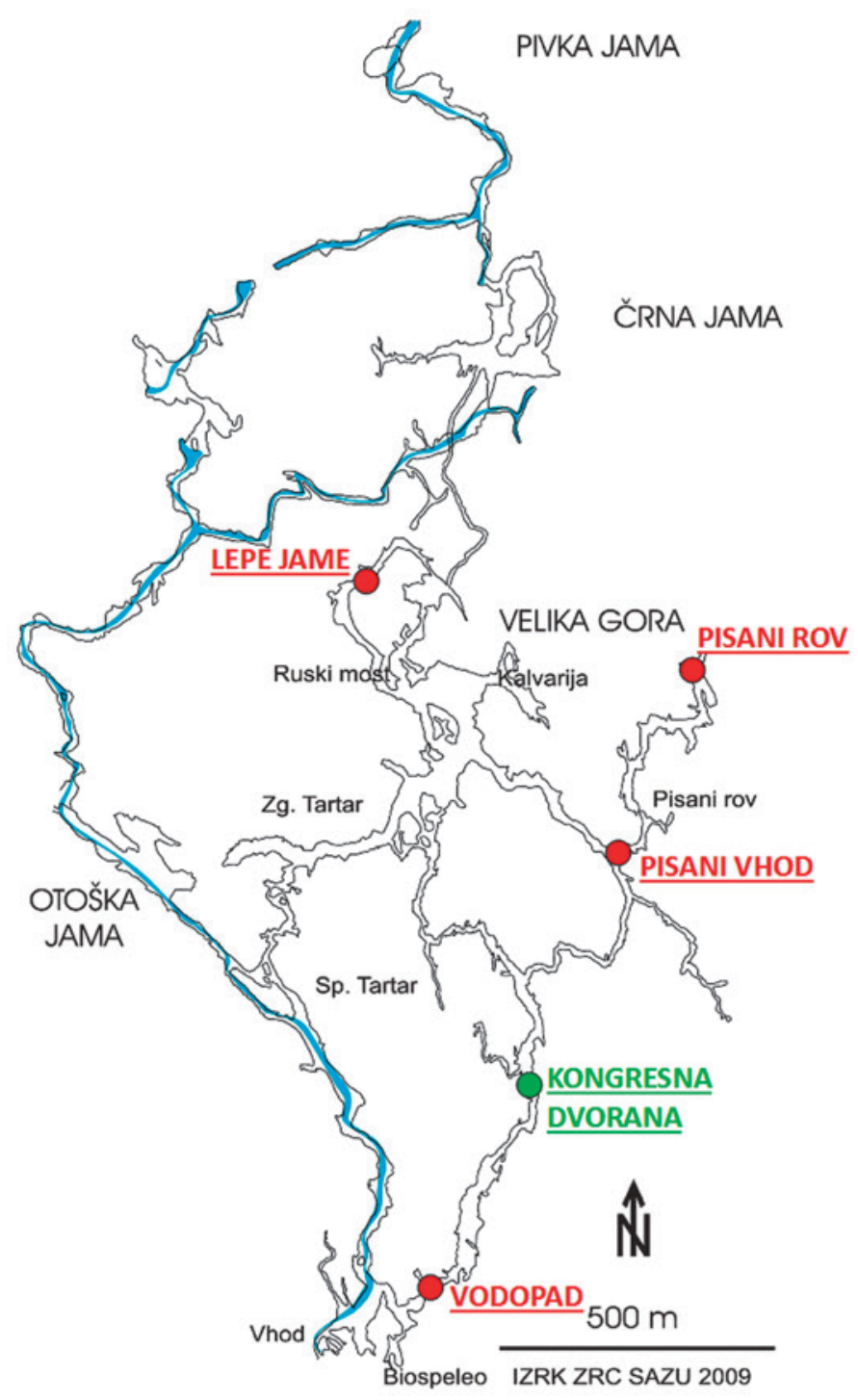

Fig. 1: Locations of automatic cave measuring stations in the Postojnska jama cave in red colour and location of the DTN gateway in green colour (author of cartography: Stanka Šebela). 
eliminating the error before the regular periodic inspection and this way preventing big gaps in data series.

A quality cave information system must ensure at least $95 \%$ availability of good data.

\section{DATA TRANSFER IN A CAVE INFORMATION SYSTEM}

Data transfer in a cave information system is a unique problem primarily because of the factors of the characteristic environment (extreme for the equipment and for the people). It is pitch dark in caves and solar radiation is available only at entrances to the caves. Caves have no visible light and high humidity, which inhibits wireless communications (Mottola et al. 2010). Caves have typically very irregular geometry, which weakens or prevents wireless communications across greater distances. All above increases the energy consumption for wireless connections. In many ways, caves present similar change this environment as space exploration, which is why caves are suitable for using and testing new DTN space technologies (Gabrovšek et al. 2014).

The application of DTN technologies is highly suitable for the cave environment, because it is resistant to interruptions and disruptions in communications, and can be adapted to various transfer techniques; as a result, the data are not exactly current, but that is not essential for a cave information system designed for scientific research.

Moreover, DTN technology is also applicable because it enables the use of an unconventional data transfer method, such as data mule on a train or in mobile phones and tablets of guides (Grašič et al. 2010, 2011; Vrbinc et al. 2010; Božnar et al. 2012; Gabrovšek et al. 2014). DTN data transfer means that the cave station embedded computer collects data and waits for the eventual encounter with a mobile computer that has a role of a "data mule". When the data mule comes into physical vicinity of a cave station embedded computer a wireless communication (WiFi) is used to establish a connection according to DTN internet protocol for certain short time interval. During this time interval data mule receives measurements data and the goes physically to another distant location where it transfers this data to another data mule or to a stationary computer (gateway) that has a legacy broadband internet connection. A typical example of a data mule is a computer mounted on a tourist train that passes by the cave station this is physically located near the train railway (Gabrovšek et al. 2014).

The main characteristics of a quality data transfer network are based on its resistance to interruptions and disruptions in communication channels:

- The system automatically attempts to restore communication during an interruption or disruption;

- Communication takes place using a standard protocol, which has the option of error detection;

- During an interruption, the data accumulate and wait until the transfer is restarted;

- When it is restarted, only the data that have not been transferred yet are transferred, and the rest are not transferred needlessly, thus not filling up the communication channels; for this reason, a transfer record is kept.

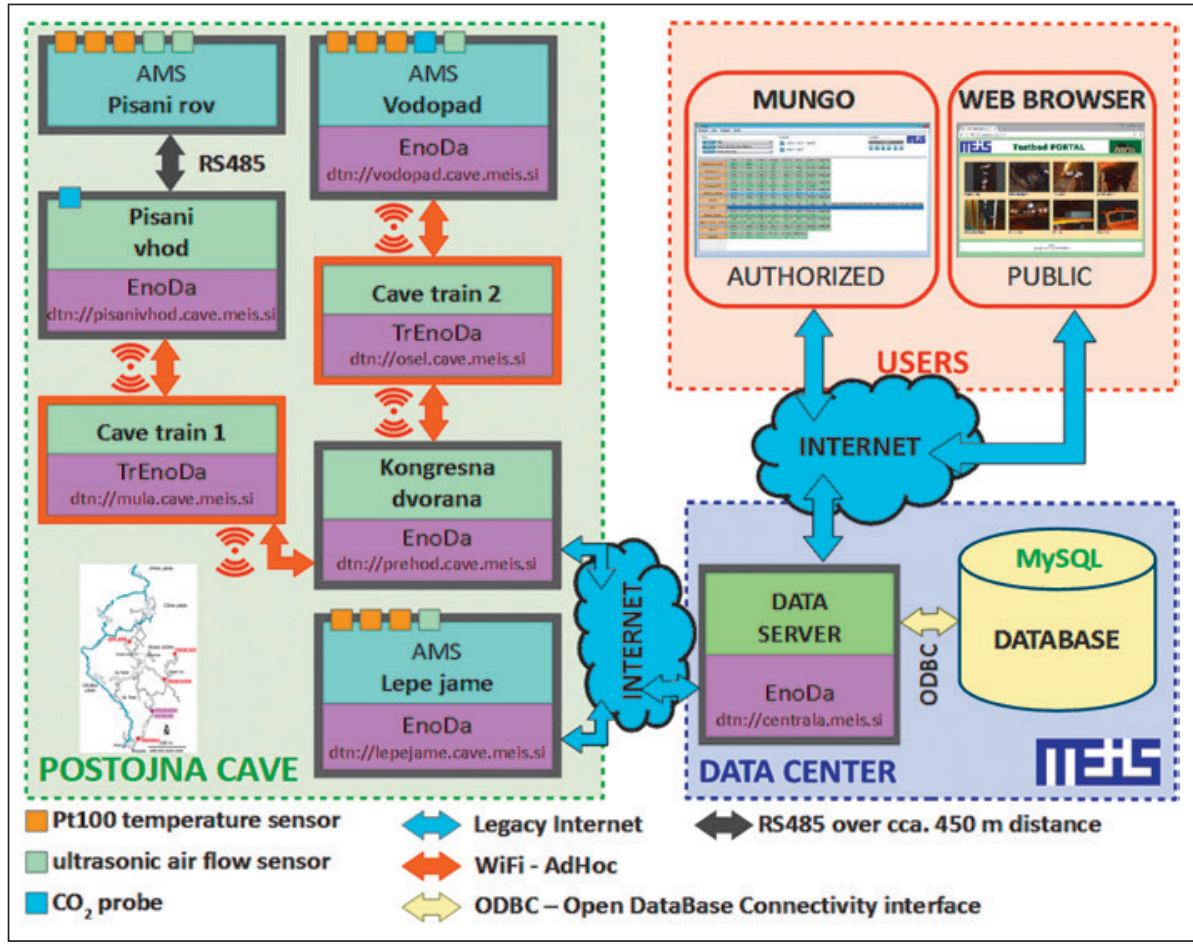

Fig. 2: Diagram of the main building blocks of the "Jam'ca" environmental information system in the Postojnska jama cave. 


\section{“JAM'CA” - CAVE INFORMATION SYSTEM OF POSTOJNA CAVE}

Cave information system (referred as Jam'ca) based on the guidelines given in the previous sections have been established in Postojna Cave. Postojna Cave is one of the most important show caves in the world and the most visited tourist destination in Slovenia (Šebela 2019). Lately, it is visited each year by over half a million tourists; since 1819 it has been visited by more than 38 million visitors.

This cave system is over $25 \mathrm{~km}$ long and with five known entrances. It has formed in Cretaceous limestone between the Pivka Basin and the Planinsko Polje. The system is in two dominant levels. The upper "tourist" level is a network of large fossil passages interrupted by breakdown chambers, all highly decorated with speleothems. The lower active level follows a system of active channels with flow of the allogenic Pivka River. The active part has been explored for over $5 \mathrm{~km}$. It continues in an unexplored sump towards the Planina Cave. The Postojnska Cave is the cradle of speleobiology and is among the caves with the greatest biodiversity on the planet (Šebela 2019).

One of the main challenges in managing show caves is how to develop cave tourism and its infrastructure with minimum impact on the sensitive cave environment, and ensure the safety of visitors and employees (Gregorič et al. 2013; Šebela et al. 2015). Besides direct physical influence during the construction of cave infrastructure, our presence and activities change the cave atmosphere (Šebela \& Turk 2014; Šebela et al. 2013). The cave microclimate is a key factor for the cave ecosystem, on which the survival of numerous endemic species depends; it also has an important impact on the preservation and deposition of flowstone (Šebela \& Turk 2011, 2018; Prelovšek et al. 2018, Pipan et al. 2019).

The map of the Postojnska jama cave (Fig. 1) shows the locations of automatic cave measuring stations in the Postojnska jama cave, which have been operating since
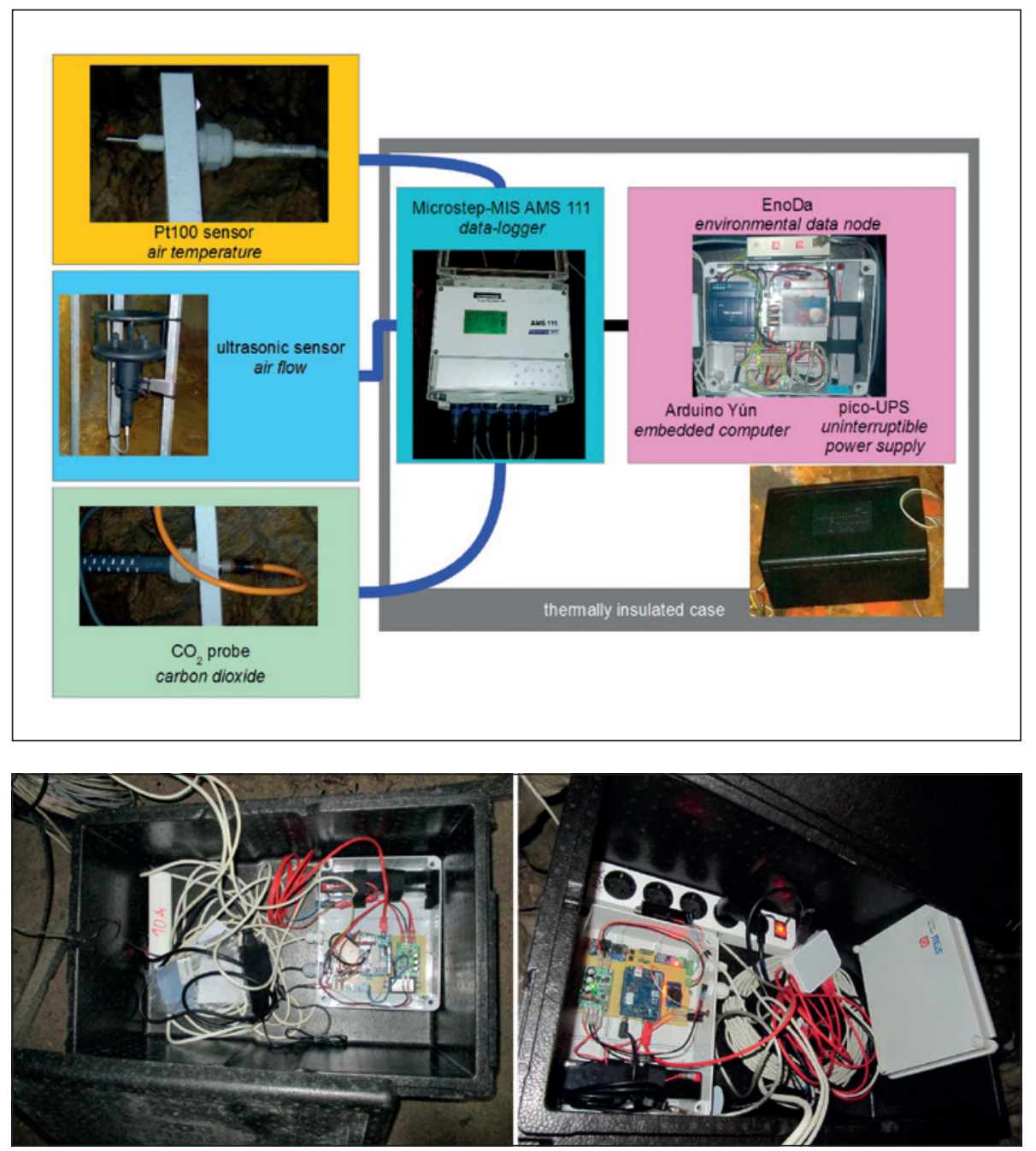

Fig. 3: Diagram of the main building blocks of the automatic cave measuring station.

Fig. 4: Pictures of the EnoDa environmental nodes in the "Vodopad" location (left) and "Lepe jame" location (right) both in a thermally insulated housing with open lid (Photo: B. Grašič). 

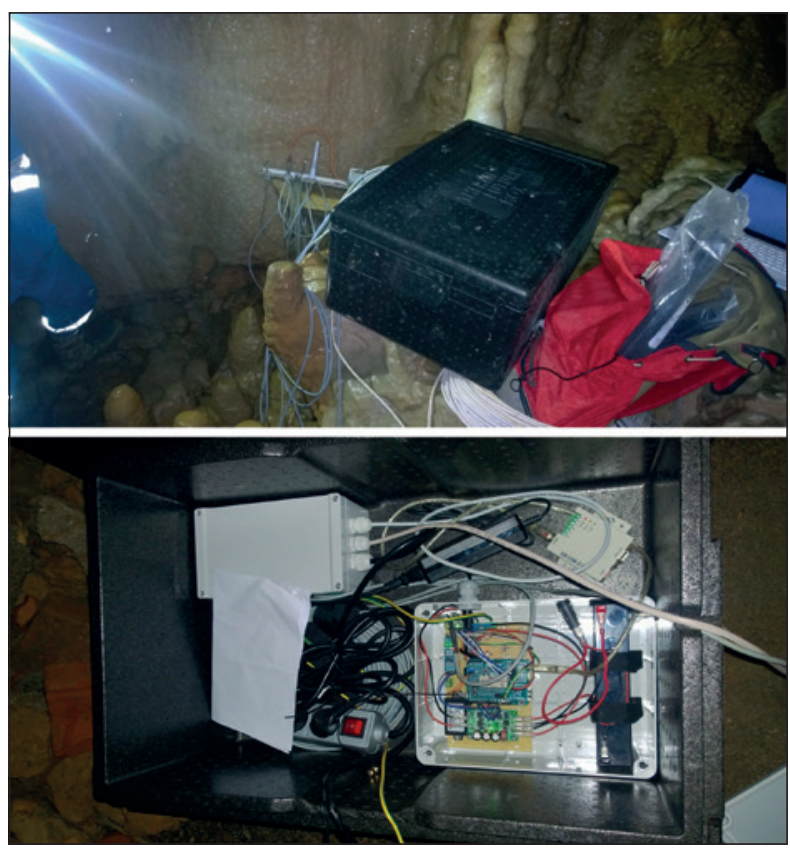

Fig. 5: Pictures of automatic cave measuring stations for performing measurements in Pisani rov (top is a picture of the thermally insulated housing in which the measuring interface is located) and at "Pisani vhod" station (bottom is a picture of the "EnoDa" environmental node, likewise in a thermally insulated housing with open lid) (Photo:B. Grašič).
2010. The locations were chosen in accordance with the purpose and the financial resources available. The "Vodopad" station describes the conditions near one of the cave entrances; the "Lepe jame" station describes the conditions in the part of the cave that is most visited by tourists; while the "Pisani rov" station describes the conditions in the part of the cave that is the most remote and free of the impact of tourists in the cave. Additionally, another gateway station is also located in the cave in the "Kongresna dvorana", where a fibre-optic Internet connection is available; the station is used above all as the main node for transferring data from the cave to the central unit outside the cave. The diagram (Fig. 2) shows the main building blocks of the "Jam'ca" environmental information system in the Postojnska jama cave.

\section{AUTOMATIC CAVE MEASURING STATION}

The main modules of the automatic measuring station are shown in the diagram (Fig. 3) and are the same for all stations in the "Jam'ca" system except for the selection and number of sensors, which is why we will give a detailed description of only the "Pisani rov" station, and its description will apply to all other stations.

The station for measuring individual environmental variables within the cave is equipped with the following sensors:
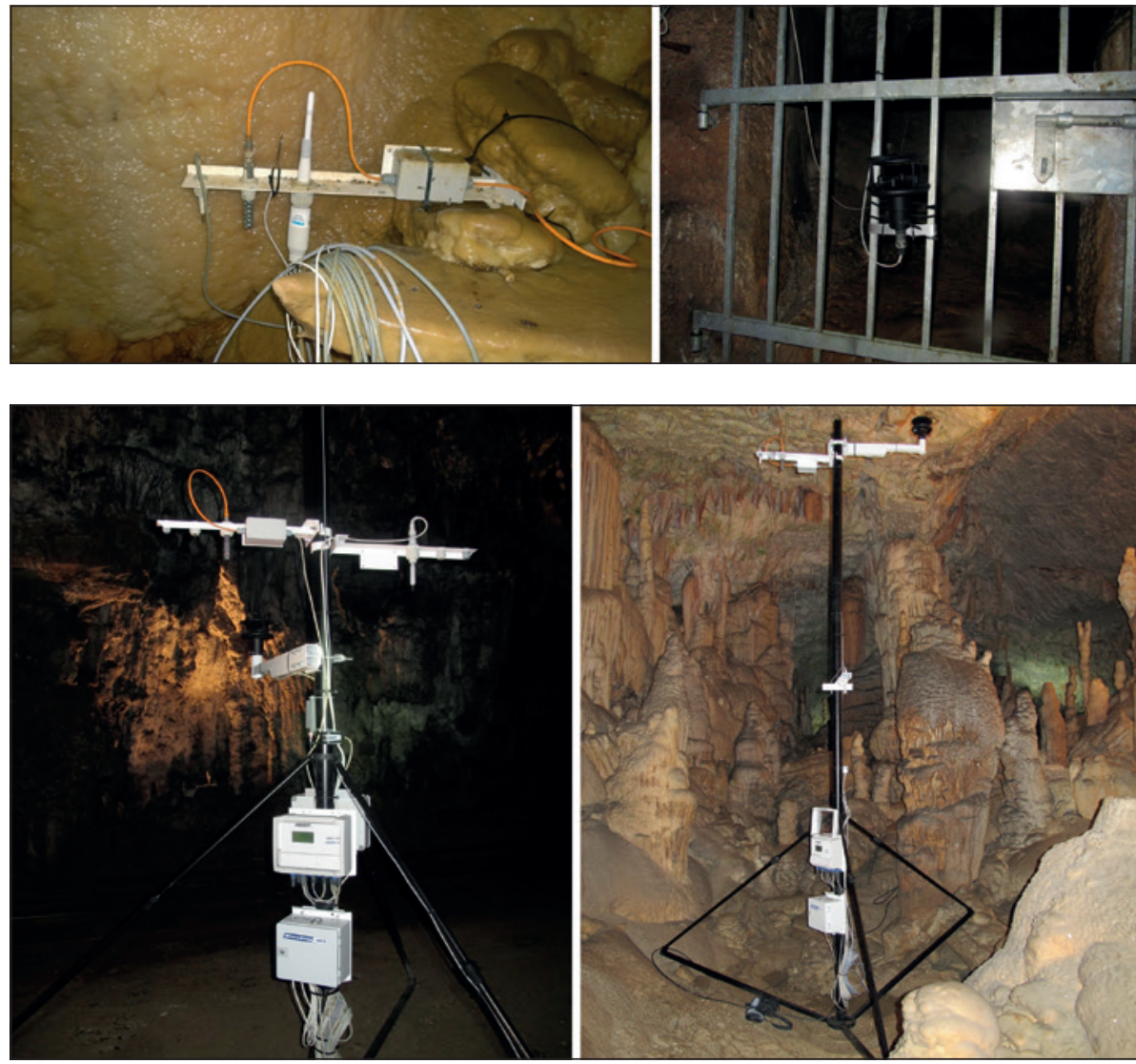

Fig. 6: Pictures of the mounting of sensors in the locations of "Pisani rov" (left) and "Pisani vhod" (right) (Photo: B. Grašič).

Fig. 7: Pictures of the mounting of sensors on portable removable measuring towers (left in the location of "Lepe jame", right in the location of "Vodopad") (Photo: F. Gabrovšek). 


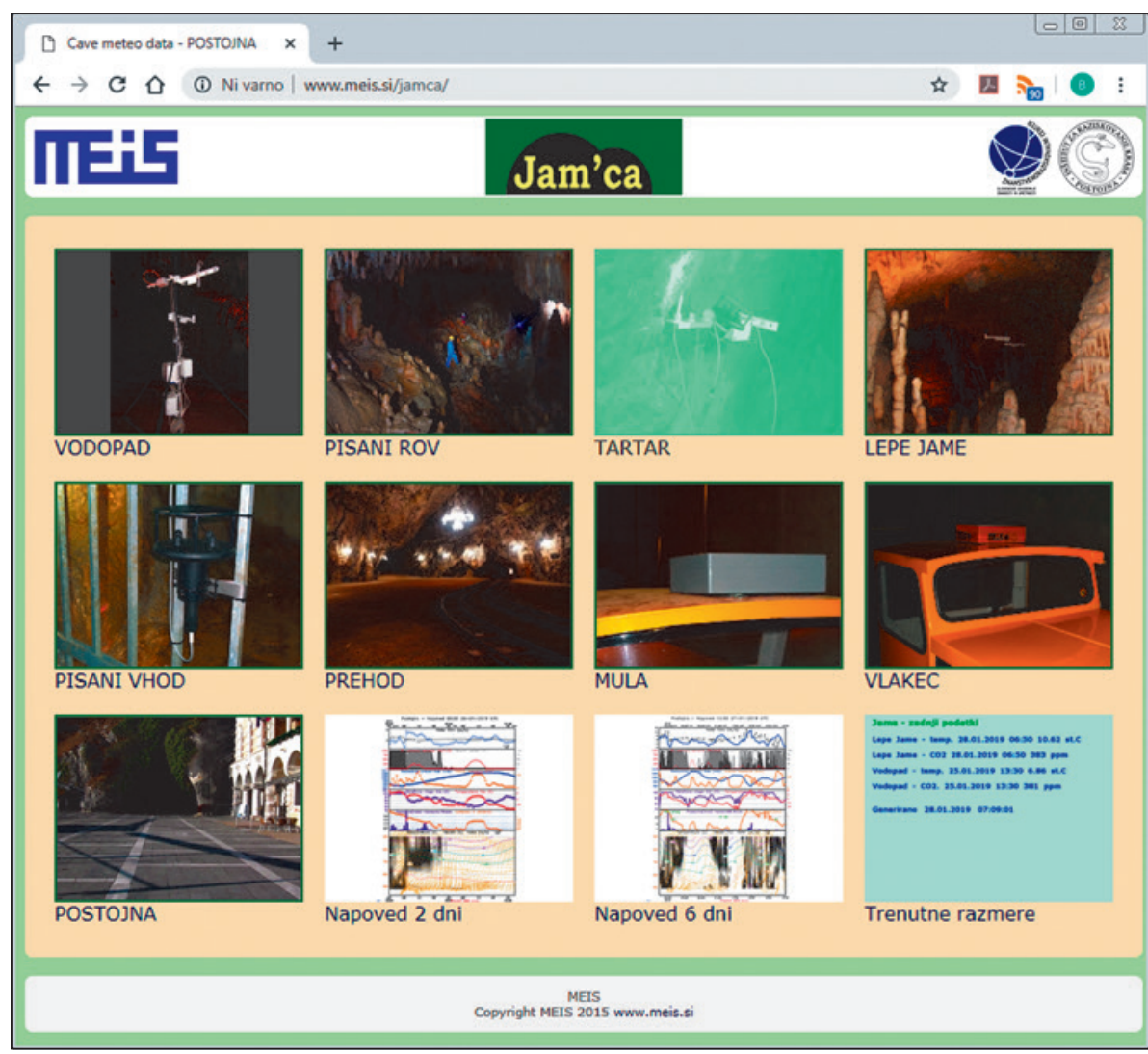

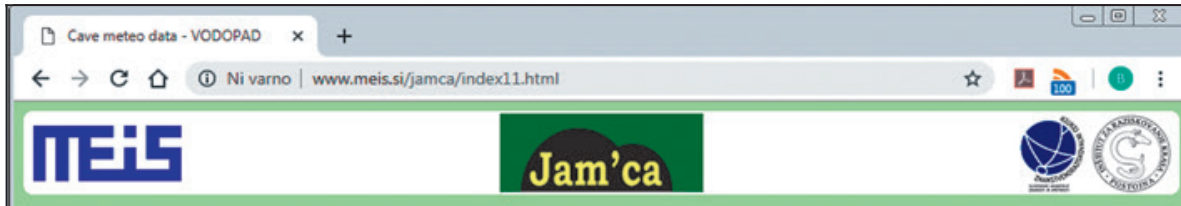

\section{Cave meteo data - VODOPAD}

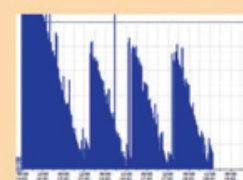

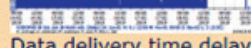
Data delivery time delay

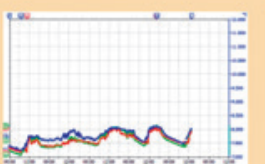

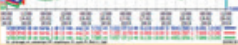

Temperatures

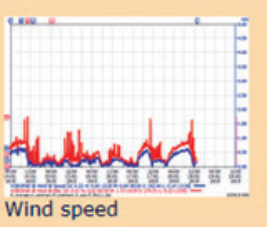

Wind speed

Wind direction

MEIS
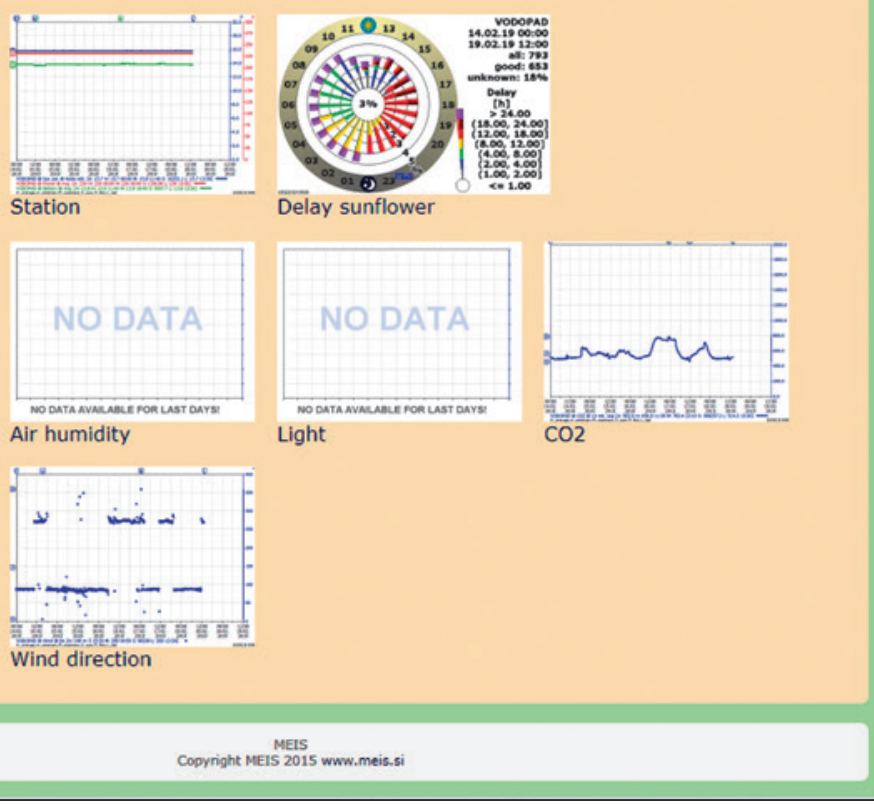

Fig. 8: The entry page of the publicly accessible website of the "Jam'ca" environmental system on the website: http://www.meis.si/jamca.
Fig. 9 The publicly accessible website of the "Jam'ca" environmental system presents last five days of data. 
- Air temperature: PT100 sensor, type "Pt100 Thermometer $1 / 5$ DIN", accuracy $\pm 0.10^{\circ} \mathrm{C}$, range from $-65^{\circ} \mathrm{C}$ to $+70^{\circ} \mathrm{C}$, response time $<20$ seconds, long-term stability $0.1^{\circ} \mathrm{C} /$ year, manufacturer MicroStep-MIS;

- Air flow: ultrasonic wind sensor, type "WindSonic", wind speed accuracy $\pm 2 \%$ at $12 \mathrm{~m} / \mathrm{s}$, wind direction accuracy $\pm 3 \%$ at $20 \mathrm{~m} / \mathrm{s}$, wind speed ranges from 0 $\mathrm{m} / \mathrm{s}$ to $60 \mathrm{~m} / \mathrm{s}$ and wind direction range from $0^{\circ}$ to $359^{\circ}$, manufacturer Gill Instruments Limited;

- Carbon dioxide $\mathrm{CO}_{2}: \mathrm{CO}_{2}$ probe, type "GMT 200 series", accuracy \pm ( $1.5 \%$ of range $+2 \%$ of reading), a range from $0 \mathrm{ppm}$ to $10000 \mathrm{ppm}$, response time $<20$ seconds, long-term stability $< \pm 5 \%$ of range $/ 2$ years, manufacturer Vaisala.

The measured data are captured (sampled and basically statistically elaborated) by the MicroStep-MIS AMS 111 data logger via the RS485 communication interface. The capture, collection, statistical processing, control, local storage and transfer to the central unit is provided by the MEIS EnoDa environmental node. The EnoDa device is based on the Arduino Yún embedded computer, which provides relatively good performance in light of its consumption (under 2 $\mathrm{W})$, a quality WiFi connection, and a permanent microSD memory medium. The EnoDa device is also equipped with quality uninterruptible power supply based on a $12 \mathrm{~V}$ leadacid battery, which enables continuous operation during a power outage up to 12 hours long or longer, depending on the battery's capacity; it also enables a controlled shut down of the device to protect the data on the memory medium. The software of the MEIS EnoDa environmental node complies with all the properties described in the subchapter "Automatic Cave Measuring Station"; a detailed description is available in the paper (Grašič et al. 2011).

All of the electronics of the cave measuring station, apart from the sensors, are installed in a suitably thermally insulated housing that prevents condensation on the housing. A simple styrofoam box originally designed for food delivery is used. EnoDa environmental nodes in the "Vodopad" and "Lepe jame" locations in such a thermally insulated housing with open lid are presented on
Fig. 4. A picture of the measuring station in the "Pisani rov" location is shown in the figures (Fig. 5). This station's special feature is the relatively great distance (about $500 \mathrm{~m}$ ) between the measuring interface in the "Pisani rov" location and the EnoDa environmental node in the "Pisani vhod" location. The EnoDa has been placed in that location because of the vicinity of the cave's railway line, which the tourist cave train occasionally passes by, equipped with a data mule for data transfer based on DTN technology (Gabrovšek et al. 2014).

The sensors have been installed in accordance with the possibilities and needs in individual locations. Whereas in the locations of "Pisani rov" and "Pisani vhod" they have been mounted on existing brackets using plastic cable ties (Fig. 6), in the locations of "Vodopad" and "Lepe jame" a removable portable tower has been used instead (Fig. 7).

\section{CENTRAL UNIT OF THE "JAM'CA" ENVIRONMENTAL CAVE SYSTEM}

The central unit of the "Jam'ca" cave system is located on the premises of MEIS and complies with all the properties described in the subchapter "Central Cave Unit".

It is made up of several computers of suitable performance:

- The EnoDa environmental node, which is the main node for receiving data via the World Wide Web (Internet) based on an Arduino Yún embedded computer, or via an Ad-Hoc wireless connection with the TrEnoDa data mule;

- A high-performance server computer, based on an Intel I7 microprocessor, 16 GB of RAM and 1 TB hard drive, with installed software for the additional control and saving of data received from the stations to the MySQL database; this computer also has installed software for accessing the archived data and transferring the measured values for the last 5 days from all stations in the form of graphs to the public website (Figs. 8-9) (Inštitut za raziskovanje krasa ZRC SAZU and MEIS 2015),

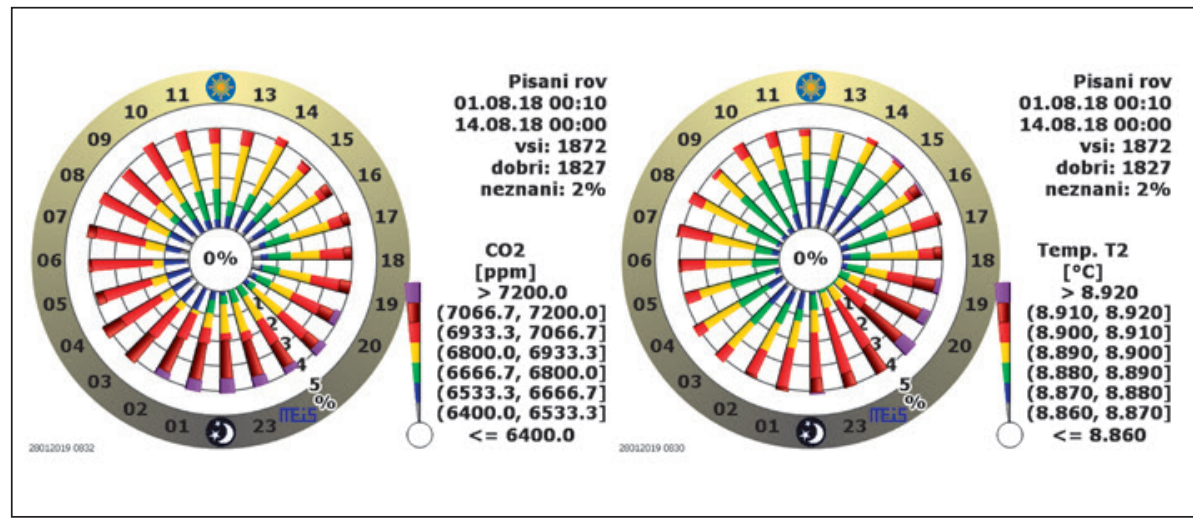

Fig. 10: Analysis of measurement data from Pisani rov using the "Sončnica/Sunflower" tool. Left: average $\mathrm{CO}_{2}$ concentration. Right: average temperature T2. The graphs are made with "webSolarRose" program. The graph shows 14 days of statistically elaborated data to find daily patterns: note that for this period the $\mathrm{CO}_{2}$ has higher values during nights, particularly between 7:30 p.m. and 2:00 a.m.. The temperature shows highest values between 6:30 p.m. and 8:30 p.m. 


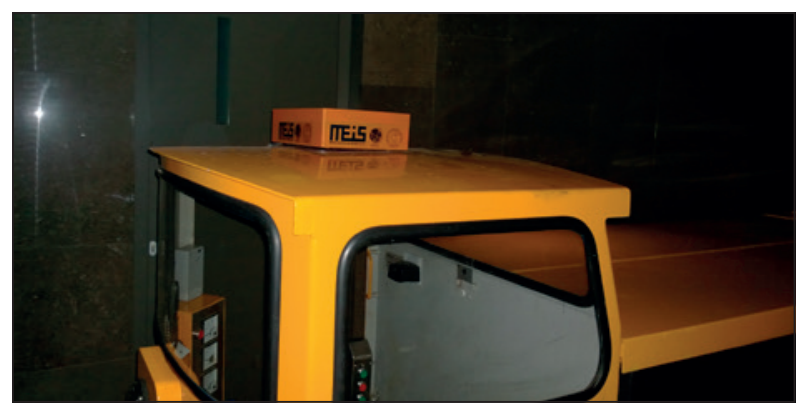

Fig. 11: A picture of a DTN data mule mounted on the tourist train in the Postojnska jama cave using a magnetic bracket (Photo: B. Grašič).

- Rented server space outside the premises of MEIS for hosting the public website;

- And a personal computer, equipped with a system for automatic warning (alarming) of detected outages or errors in the "Jam'ca" system via emails and short text messages.

Access to all current and historical data is enabled by means of a dedicated "Mungo" display program, which enables reviews, graphic presentations and statistical displays for scientific purpose even outside the internal MEIS network on personal computers. Other dedicated tools are also available for visualisation and statistical processing, such as the "webSolarRose" program for drawing suflower diagrams (Fig. 10).

\section{DTN DATA TRANSFER}

In the "Jam'ca" environmental cave system, DTN data transfer technology is used for data transfer; it is presented in the subchapter "Data Transfer in a Cave Information System". Two TrEnoDa DTN data mules (Fig. 11) are used for data transfer. They are mounted each one on its own tourist train and they alternate when the batteries run out of power. The TrEnoDa data mule contains a vibration sensor for saving energy; it makes sure that the TrEnoDa switches off when the train is not moving. This and the capacity of seven single-cell LiPo batteries, amounting to $42 \mathrm{Ah}$, ensure autonomous operation for approximately 25 days. When passing a stationary cave station, the data mule has on average 10-15 seconds available to exchange data. More details can be found in paper by Gabrovšek et al. (2014).

\section{CONCLUSIONS}

The article has presented the technology behind the construction of automatic micrometeorological cave measuring stations and systems for the scientific study of karst caves. We have presented the automatic measuring stations, the communication and mobile nodes, and the central unit; we name this the "cave information system for the scientific study of the micrometeorology of karst caves".
We have described specific examples of possibilities for implementing individual components in practice. We have mentioned the key characteristics of individual components and their essential functionalities. We have substantiated its implementation with examples of the implementation of such a system in the Postojnska jama karst cave in Slovenia.

\section{ACKNOWLEDGMENT}

The authors acknowledge that the projects ("Methodology for monitoring the sustainable use of karst show caves with automatic measurements - role model - Postojna cave", ID L6-9397, "Karst research for sustainable use of Škocjan Caves as World heritage", L2-8174 and
"Assesment of natural and anthropogenic processes in micrometeorology of Postojna cave system by numerical models and modern methods of data acquisition and transfer", ID L6-2156) were financially supported by the Slovenian Research Agency.

\section{REFERENCES}

Božnar, M.Z., 2004: Environmental information systems in Slovenia---the present and future state.- Il nuovo cimento della Società Italiana di fisica, 27C, 4, 307315. https:doi.org/10.1393/ncc/i2004-10022-2
Božnar, M.Z., Mlakar, P., Grašič, B. \& F. Gabrovšek, 2012: "E-learning" lectures for setting up a modern DTN communications based cave micrometeorological stations, example of Postojna Cave.- In: Šebela, S. 
(ed.) Guide book and abstracts, International Congress on "Scientific Research in Show Caves", $13^{\text {th }}-15^{\text {th }}$ September, 2012, Škocjan. Inštitut za raziskovanje krasa ZRC SAZU, 16-17, Postojna.

Božnar, M.Z., Grašič, B., Mlakar, P., Soares, J., de Oliveira, A.P. \& T.S. Costa, 2015: Radial frequency diagram (sunflower) for the analysis of diurnal cycle parameters: Solar energy application.- Applied Energy, 154, 592-602. https://doi.org/10.1016/j.apenergy.2015.05.055

Cigna, A.A., 2002: Modern Trend in Cave Monitoring.- Acta Carsologica 31, 1, 35-54. https://doi. org/10.3986/ac.v31i1.402

European Union, 2014: Directive 2014/35/EU of the European Parliament and of the Council of 26 February 2014 on the harmonisation of the laws of the Member States relating to the making available on the market of electrical equipment designed for use within certain voltage limits.-[Online] Available from: https://eur-lex.europa.eu/legal content/EN/ TXT/?uri=CELEX:32014L0035 [Accessed 2nd November 2020].

Gabrovšek, F., Grašič, B., Božnar, M.Z., Mlakar, P., Udén, M. \& E. Davies, 2014: Karst show caves - how DTN technology as used in space assists automatic environmental monitoring and tourist protection - experiment in Postojna Cave.- Natural Hazards and Earth System Sciences 14, 443-457. https://doi. org/10.5194/nhess-14-443-2014

Grašič, B., Mlakar, P., Božnar, M.Z. \& M. Lesjak, 2003: Use of open source operating system and TCP/IP connectivity in urban environmental monitoring.In: Jezernik, K. et al. IEEE International Conference on Industrial Technology, $10^{\text {th }}-12^{\text {th }}$ December 2003, Maribor, IEEE, 1257-1261, Maribor. https://doi. org/10.1109/ICIT.2003.1290846

Grašič, B., Mlakar, P., Božnar, M.Z., Popović, D. \& F. Gabrovšek, 2017a: Automatic measurements in Postojna cave.- In: Gostinčar, P. (ed.) Milestones and Challenges in Karstology: Abstracts \& Guide Book, 25th International Karstological School "Classical Karst”, $19^{\text {th }}-23^{\text {rd }}$ June 2017, Postojna. Založba ZRC, 27-28, Ljubljana.

Grašič, B., Mlakar, P., Božnar, M.Z., Popović, D., Kokal, D. \& F. Gabrovšek, 2017b: Izvedba in zagotavljanje kakovostnih avtomatskih meritev za znanstveno proučevanje mikrometeorologije kraških jam.- In: Kuhar, M. et al. (eds.) Raziskave s področja geodezije in geofizike 2016: zbornik del, 22. srečanje Slovenskega združenja za geodezijo in geofiziko, $26^{\text {th }}$ January 2017, Ljubljana. Univerza v Ljubljani, Fakulteta za gradbeništvo in geodezijo. 51-67, Ljubljana.

Grašič, B., Vrbinc, S., Božnar, M.Z., Mlakar, P. \& D.
Popović, 2010: Delay and Disruption Tolerant Networking (DTN) test bed in Slovenia.- In Orel,.M.(ed.): The new vision of future technologies, International Conference InfoKomTeh 2010, $27^{\text {th }}$ October 2010,Eduvision, 103-114, Polhov Gradec.

Grašič, B., Vrbinc, S., Mlakar, P. \& M.Z. Božnar, 2011: Software applications for environmental measurements using DTN connectivity.- In Jezernik, K. (ed.) Proceedings of the 14th International Multiconference Information Society - IS 2011, Volume $A, 10^{\text {th }}-14^{\text {th }}$ October, 2011, Ljubljana. Institut Jožef Štefan, 207-210, Ljubljana.

Gregorič, A., Vaupotič, J. \& F. Gabrovšek,2013: Reasons for large fluctuation of radon and $\mathrm{CO} 2$ levels in a dead-end passage of a karst cave (Postojna Cave, Slovenia).-Nat. Hazards Earth Syst. Sci. 13/2, 287297. https://doi.org/10.5194/nhess-13-287-2013

International Organization for Standardization, 1992: ISO/IEC 9075:1992 Information technology - Database languages - SQL.- [Online] Available from: https://www.iso.org/standard/16663.html [Accessed 1st December 2020].

Lesjak, M., Diallo, B., Mlakar, P., Rupnik, Z., Snajder, J. \& B. Paradiž, 1989: Computerised ecological monitoring system for the Šoštanj thermal power plant.In: Brasser, L.J \& W.C. Mulder (eds.) Man and His Ecosystem: Proceedings of the 8th World Clean Air Congress $1989,11^{\text {th }}-15^{\text {th }}$ September 1989 , Hague. Elsevier Science Publishers B.V., 3-31, Amsterdam.

Lesjak, M., Božnar, M.Z. \& P. Mlakar, 1999a: Internet applications as a link between the environmental information systems and public.- Transactions on Ecology and the Environment, 29, 111-120.

Lesjak, M., Mlakar, P. \& M.Z. Božnar, 1999b: Design, Construction And Exploitation Of The Environmental Information Systems.- WIT Transactions on ecology and environment, 25, 309-316. [Online] Available from: https://www.witpress.com/Secure/ elibrary/papers/ENV98/ENV98030FU.pdf [Accessed 1st December 2020].

Lesjak, M., Grašič, B., Božnar, M Z. \& P. Mlakar, 2002: New Internet connected air pollution monitoring network of Slovenia.- WIT Transactions on ecology and environment, 51, 185-190. [Online] Available from: https://www.witpress.com/elibrary/wit-transactions-on-ecology-and-the-environment/51/361 [Accessed 1st December 2020].

Marikovičová, J., Omelka, J. \& A. Krovina, 2015: Introducing ICEMS - the Integrated Caves Environmental Monitoring System.- BCRA cave radio \& electronics group journal, 90, 20-21.

Mlakar, P., Diallo, B., Lesjak, M. \& I. Čuhaljev, 1990: Avtomatizirano vrednotenje kvalitete podatkov 
v računalniških ekoloških merilnih sistemih.- In Drnovšek, J. et al (Eds.): Programska merilna oprema: zbornik referatov. Elektrotehniška zveza Slovenije, pp.77-83, Ljubljana.

Mlakar, P. \& M.Z. Božnar, 1995: Environmental information systems in Slovenia.- WIT Transactions on ecology and environment, 10, 259-266. [Online] Available from: https://www.witpress.com/elibrary/ wit-transactions-on-ecology-and-the-environment/10/9710 [Accessed 1st December 2020].

Mlakar, P., Božnar, M.Z. \& M. Lesjak, 1999: Implementation of a modern meteorological and radiological early warning system in Algeria.- WIT Transactions on ecology and environment, 37, 1065-1072. https://doi.org/10.2495/AIR991031

Mlakar, P., Božnar, M.Z. \& B. Grašič, 2006: Mobile automatic weather and air pollution system (MWS).In: European Meteorological Society: Sixth Annual Meeting of the European Meteorological Society $(E M S)$ \& Sixth European Conference on Applied Climatography (ECAC), $4^{\text {th }} 8^{\text {th }}$ September 2006, Ljubljana. European Meteorological Society, Agencija RS za okolje, Ljubljana.

Mlakar, P., Božnar, M.Z. \& B. Breznik, 2014: Operational air pollution prediction and doses calculation in case of nuclear emergency at Krško.- International journal of environment and pollution, 54, 2-4, 184192. https://doi.org/10.1504/IJEP.2014.065119

Mlakar, P., Božnar, M.Z., Grašič, B. \& B. Breznik, 2019: Integrated system for population dose calculation and decision making on protection measures in case of an accident with air emissions in a nuclear power plant.- Science of The Total Environment, 666, 786800. https:doi.org/10.1016/j.scitotenv.2019.02.309

Mottola, L., Picco, G.P., Ceriotti, M., Gună, Ş. \& A.L. Murphy, 2010: Not All Wireless Sensor Networks Are Created Equal: A Comparative Study on Tunnels.- ACM Transactions on Sensor Networks, 7, 2, 15. https://doi.org/10.1145/1824766.1824771

Novas, N., Gázquez, J.A., MacLennan, J., García, R.M., Fernández-Ros, M. \& F. Manzano-Agugliaro, 2017: A real-time underground environment monitoring system for sustainable tourism of caves.- Journal of Cleaner Prodution, 142, 4, 2707-2721. https://doi. org/10.1016/j.jclepro.2016.11.005

Pipan, T., Petrič, M., Šebela, S. \& D.C. Culver, 2019: Analyzing climate change and surface-subsurface interactions using the Postojna Planina Cave System (Slovenia) as a model system.-Regional environmental change, 19, 2, 379-389. https://doi. org/10.1007/s10113-018-1349-z

Prelovšek, M., Šebela, S. \& J. Turk, 2018: Carbon dioxide in Postojna Cave (Slovenia): spatial distribu- tion, seasonal dynamics and evaluation of plausible sources and sinks.- Environmental earth sciences, 77, 7, 1-15. https://doi.org/10.1007/s12665-0187459-6

Shannon, C.E., 1949: Communication in the presence of noise.- Proceedings of the IRE, 37, 1, 10-21. https:// doi.org/10.1109/JRPROC.1949.232969

Šebela, S. \& J. Turk, 2011: Local characteristics of Postojna Cave climate, air temperature, and pressure monitoring.- Theoretical and applied climatology, 105, 3-4, 371-386. https://doi.org/10.1007/s00704011-0397-9

Šebela, S., Prelovšek, M. \& J. Turk, 2013: Impact of peak period visits on the Postojna Cave (Slovenia) microclimate.- Theoretical and applied climatology, 111, 1-2, 51-64. https://doi.org/10.1007/s00704-0120644-8

Šebela, S \& J. Turk, 2014: Natural and anthropogenic influences on the year-round temperature dynamics of air and water in Postojna show cave, Slovenia.Tourism management, 40, 233-243. https://doi. org/10.1016/j.tourman.2013.06.011

Šebela, S., Turk, J. \& T. Pipan, 2015: Cave micro-climate and tourism: Towards 200 years (1819-2015) at Postojnska jama (Slovenia).-.Cave and karst science: the transactions of the British Cave Research Association, 42, 2, 78-85.

Šebela, S. \& J. Turk, 2018: Črna Jama as a cold air trap cave within Postojna Cave, Slovenia.-Theoretical and applied climatology, 134, 3-4, 741-751. https:// doi.org/10.1007/s00704-017-2304-5

Šebela, S., 2019: Postojna-Planina Cave System, Slovenia.- In: White et al. (eds) Encyclopedia of Caves 3rd edition. Elsevier, Academic Press, pp. 812-821. https://doi.org/10.1016/B978-0-12814124-3.00098-4

Vrbinc, S., Grašič, B., Božnar, M.Z. \& P. Mlakar, 2010: SymbioNode Data Carrier in Delay and Disruption Tolerant Networking (DTN).- In: Bohanec, M. et al. (eds.) Proceedings of the 13th International Multiconference Information Society - IS 2010, Volume $A, 11^{\text {th }}-15^{\text {th }}$ October 2010, Ljubljana. Inštitut Jožef Štefan, 1-6, Ljubljana.

World Meteorological Organization, 2008: Guide to Meteorological Instruments and Methods of Observation. WMO-No. 8.- [Online] Available from: https://www.weather.gov/media/epz/mesonet/ CWOP-WMO8.pdf [Accessed 1st December 2020].

Zelinka, J., 2002: Microclimatic Research in the Slovakian Show Caves.- Acta Carsologica 31, 1, 151-163. https://doi.org/10.3986/ac.v31i1.410 